\title{
Minimum tillage and no-tillage winter wheat-summer fallow for low precipitation regions
}

\section{J.D. Williams and S.B. Wuest}

\begin{abstract}
Dryland wheat (Triticum aestivum L.) is the principal crop grown on 3.35 million ha $(8.28$ million ac) of the semiarid Inland Pacific Northwest of the United States. In areas with less than $300 \mathrm{~mm}$ (12 in) of annual precipitation, challenges for wheat production are similar to those found in the Mediterranean region and Australia. Successful crop production depends on adequate precipitation capture and storage and weed control, which prove problematic under no-tillage (NT), the most effective soil conservation practice. Sweep-tillage (ST) is proposed as an equally effective conservation system, with local conventional wisdom saying that it produces higher yields than NT systems. A study established in 2006 and concluded in 2018 evaluated the performance of NT and ST winter wheat-summer fallow production systems. The null hypothesis for this research assumed no statistically significant differences in any of the soil and plant characteristics measured between NT and ST treatments. Sixteen 0.04 ha $(0.10 \mathrm{ac})$ plots were established in a randomized complete block design, with two rotation entry points for a total of four treatment plots per year replicated in four blocks. Data were analyzed using a generalized linear mixed model. The NT system produced significantly higher crop yields and higher precipitation use efficiencies than the ST system (NT $3.38 \pm 0.33, \mathrm{ST} 2.66 \pm 0.27 \mathrm{Mg} \mathrm{ha}^{-1}$ [NT $\left.50 \pm 5, \mathrm{ST} 40 \pm 4 \mathrm{bu} \mathrm{ac}^{-1}\right]$ ). Infiltration rates were higher and soil temperatures were lower in the NT system. The higher yields and lower soil temperatures in the NT system were unexpected and contrary to previous research conducted in this region.
\end{abstract}

Key words: minimum tillage — summer fallow — undercutter-no-tillage — crop residue conservation-winter wheat

\begin{abstract}
Winter wheat (Triticum aestivum L.) is among the most productive and profitable crops grown in rainfed agricultural regions of the world. The mild, wet winters and hot, dry summers in the Pacific Northwest (United States) are ideal for rainfed soft white winter wheat production using a two-year winter wheat-14-month fallow system. With crop production of approximately 3.4 $\mathrm{Mt} \mathrm{ha}^{-1}$ per two-year rotation (48 bu $\mathrm{ac}^{-1}$ ) (Schillinger and Papendick 2008), this system remains the economic mainstay of the region. Until recently, this level of production was dependent on tillage for weed control and soil water manipulation, in which all residues were buried to create a
\end{abstract}

"black" fallow. This system produces acceptably reliable wheat yields under variable annual weather conditions of temperature and precipitation, but it also results in unsustainable soil and nutrient loss (Gollany et al. 2011; Williams et al. 2014; Zuzel 1994). Conservation tillage systems were developed to reduce or eliminate these problems.

The most effective reduced tillage system, no-tillage (NT), substantially reduces erosion (Sharratt and Feng 2009; Williams et al. 2014). Unfortunately, some early adopters of NT in the late 1970 s and early 1980s had spectacular decreases in yield; university- and USDA-led research projects recorded yield losses of up to $50 \%$ (Smiley et al. 2013). Nearly all the

Received March 6, 2020; Revised October 13, 2020; Accepted October, 20 2020; Published online April 17, 2021. early adopters were unable to continue their efforts to produce dryland wheat using NT. A second wave of NT adoption in the Pacific Northwest began in the late 1990s and early 2000 s with the advent of improved wheat varieties, herbicides, and equipment; research in the intermediate precipitation zone $(300$ to $450 \mathrm{~mm}$ [12 to $16 \mathrm{in}$ ] mean annual precipitation) and producer experience provided evidence that NT could meet or exceed tillage-based production in two-year wheatfallow rotations (Williams and Long 2011). As of 2013, the adoption of NT or other conservation tillage methods were practiced in 70\% of the region, including substantial increases in areas with $<300 \mathrm{~mm}$ (12 in) mean annual precipitation, the low precipitation zone (Bista et al. 2017). This change in practices led to substantially more residue covering the ground and a substantial reduction in soil erosion by wind and water (Sharratt et al. 2017). However, not all impediments to NT adoption have been resolved.

Apparent impediments to successful NT adoption include combinations of the following: insufficient seed-zone water from mid-August to mid-September, insulation by residue reducing the accumulation of heat units resulting in poor crop establishment in late fall plantings, increased bulk density near the soil surface, poor weed control and the development of herbicide resistant weeds, and increased disease loading. Consequently, NT adoption has remained lower in the low precipitation zone of east central Washington and north central Oregon. Sufficient autumn precipitation to replenish soil water for germination and establishment often does not arrive until late October to mid-November (Thorup-Kristensen et al. 2009). In black-fallow or conservation tillage systems, breaking the capillary continuity to the soil subsurface conserves soil water with a tilled soil mulch through the summer, making seeding possible from mid-August and early September (Al-Mulla et al. 2009; Schillinger and Bolton 1993). Winter wheat seeded this early in the crop cycle significantly outpro-

John D. Williams is a research hydrologist at the USDA Agricultural Research Service, Soil and Water Conservation Research Unit, Adams, Oregon, United States. Stewart B. Wuest is a soil scientist at the USDA Agricultural Research Service, Soil and Water Conservation Research Unit, Adams, Oregon, United States. 
duces mid- and late-fall seeding by up to $30 \%$ (Donaldson et al. 2001), more so in the northern end of the region where growing degrees accumulate slower with substantially less precipitation (unpublished data comparing Echo, Oregon, with Lind, Washington). Thus, some producers continue to look for and evaluate variations on reduced tillage.

One of the most promising reduced tillage operations developed in the last 30 years is the undercutter or sweep-tillage (ST). Like the traditional black-fallow system, special deep-furrow seed drills are used to plant deep into soil moisture. Unlike the traditional system, tillage is limited to once in late spring or early summer with the undercutter. The ST system depends on herbicides for primary weed control throughout the first 10 to 12 months of fallow to reduce fuel, equipment, and time costs needed for tillage. This single, once-per-crop-cycle tillage is intended to reduce the capillary continuity very near the soil surface, while leaving all the crop residue on the soil surface for erosion control and to provide insulation during the hottest days of the year, thus reducing evaporative losses. The desired result is to make seeding possible before the end of the dry summer period (late August through mid-September), allowing wheat to germinate ahead of weeds and providing time for seedling wheat to become winter hardy and establish a deep root system. If successful, this practice will meet the needs of producers faced with growing herbicide resistance by weeds such as cheat grass (Bromus tectorum L.) and Russian thistle (Salsola tragus L.) or those who have found other intractable problems with the adoption of NT.

An experiment to compare NT to ST was established in 2006. Comparisons of the two systems address issues of tilled soil versus NT, which also involves early versus late seeding, seed-row fertilizer differences, and surface residue differences. The working null hypothesis for this research is that no statistically significant differences exist between treatments for any of the soil and plant characteristics measured with the primary goal of comparing crop yields in the two systems. Local conventional wisdom suggested that the ST with early seeding would produce higher yields than the NT.

\section{Materials and Methods}

This research was conducted $21.5 \mathrm{~km}(13.4$ mi) west-northwest of Pendleton, Oregon $\left(45^{\circ} 43^{\prime} \mathrm{N}, 119^{\circ} 03^{\prime} \mathrm{W}\right)$. Elevation at the site is $\sim 320 \mathrm{~m}(1,050 \mathrm{ft})$, with $2 \%$ slope on a north-northeast aspect. A meteorological station located at the site since 2001 recorded precipitation, wind speed and direction, solar radiation, relative humidity, and air and soil temperature. Mean annual precipitation based on 17 crop years (September to August) was $270.5 \pm 22.0 \mathrm{~mm}$ (10.65 \pm 0.87 in), with $91 \%$ falling during the winter wheat growth and grain fill period from October through June, placing this site in the low precipitation zone of the Inland Pacific Northwest (Schillinger and Papendick 2008). Mean annual temperature for the period of record was $11.7^{\circ} \mathrm{C}\left(53.6^{\circ} \mathrm{F}\right)$ with a maximum of $45.6^{\circ} \mathrm{C}\left(114.1^{\circ} \mathrm{F}\right)$ and a minimum of $-24.2^{\circ} \mathrm{C}\left(-11.6^{\circ} \mathrm{F}\right)$. Damaging temperatures are infrequent, with crown-damaging cold or hot temperatures affecting grain fill less than $1 \%$ of the time (figure 1). Frostfree conditions range from 150 to 170 days between May and September, with transient snow cover resulting from maritime fronts that produce low intensity storms. The soil was a Ritzville silt loam (coarse-silty, mixed, superactive, mesic Calcidic Haploxerolls in US classification system; Haplic Kastanozems in Food and Agriculture Organization [FAO]) containing <15\% sand, 5\% 10\% clay, and $\geq 75 \%$ silt on $2 \%$ to $7 \%$ slopes (FAO 1997; Johnson and Makinson 1988).

Two cropping systems were established in 2006 to evaluate the effect of tillage practices on crop production and soil characteristics in a two-year winter wheat-summer fallow (WW-SF) rotation. The ST fallow consisted of one pass of a wide-blade (81 cm [31.9 in]), minimal soil inversion undercutter sweep in the spring or early summer of the fallow year at a depth of $14 \mathrm{~cm}$ (5.5 in), resulting in a surface mulch with bulk density of $1.13 \mathrm{~g} \mathrm{~cm}^{-3}\left(0.04 \mathrm{lb} \mathrm{in}^{-3}\right)$. The undercutter sweep operation is intended to kill weeds, break capillary pore connection between soil surface and profile, maintain surface roughness, and not bury residue (Schillinger 2001; Schillinger 2007; Zaiken et al. 2008) Liquid fertilizer was applied through two tubes located under each sweep. Additional weed control was accomplished by herbicide applications. Winter wheat was seeded with a deep-furrow drill in September except for two years when the seed zone was very dry (approximately permanent wilting point). The goal was to put seeds into damp soil $(>-0.8 \mathrm{MPa})$ for immediate germination and stand establishment. Mid-September seeding occurs later than in locations farther north but is common for this location where winters are milder.

In the NT treatment, weeds were controlled with herbicides throughout the fallow period. Winter wheat was seeded and fertilized in mid-October if soil water was available; with inadequate soil water, planting was postponed until late October in anticipation of November precipitation. NT seeding was completed with a one-pass system using a Conserva-Pak (Indian Head, Saskatchewan, Canada) medium disturbance hoe-opener drill equipped on $305 \mathrm{~mm}$ (120 in) spacing. Fertilizer was placed $25 \mathrm{~mm}$ (1 in) below and $25 \mathrm{~mm}$ (1 in) to the side of the seed.

Wheat cultivars, planting dates, and seed and fertilizer rates differed from year to year (table 1). Producers traditionally sow early seeded wheat at lower rates to reduce costs and control excessive vegetative growth because the long early growing period promotes tillering and production of an adequate number of heads. Late seeding uses greater seed rates than early seeding to make up for reduced heat units needed for tillering before winter. Late seeding with NT drills are also most commonly supplied with starter fertilizer, including phosphorus $(\mathrm{P})$ as it apparently aids in stand establishment and often produces a small but measurable yield increase (Lutcher et al. 2010). Yields of early seeded winter wheat into tilled soil at this location rarely respond to $\mathrm{P}$ fertilizer. For both of our early and late seeding treatments, the nitrogen $(\mathrm{N})$ application was based on a soil test for each treatment and a recommended $0.04 \mathrm{~kg} \mathrm{~N} \mathrm{~kg}^{-1}$ wheat $(0.04 \mathrm{lb}$ of $\mathrm{N} \mathrm{bu}^{-1}$ ) of expected yield. In-crop herbicides were applied as needed for weed control. A complete list of pesticides, active ingredients, and manufactures is given in supplemental table S1.

Sixteen $7.3 \mathrm{~m} \times 54.9 \mathrm{~m}(24 \mathrm{ft} \times 180 \mathrm{ft})$ plots were established in a randomized complete block design, with two rotation entry points for a total of four treatment plots per year replicated in four blocks. Soil water was measured between harvest time and autumn precipitation in 2009, 2010, 2011, 2013, and 2015 to evaluate soil water accumulation and crop-soil-water use. To compare treatments with different surface soil bulk densities (Wuest 2009), depths were compared at equivalent mass depths $(50,100,125,225$, and $550 \mathrm{~kg} \mathrm{~m}^{-2}[10.24,20.48,25.60,46.08$, 


\section{Figure 1}

(a) Minimum and (b) maximum air temperatures from 2001 to 2017 at the research site, and the percentage of days when temperatures were (c) cold enough to cause wheat crown damage or (d) hot enough to cause damaging heat stress $\left(45^{\circ} 43^{\prime} \mathrm{N}, 119^{\circ} 03^{\prime} \mathrm{W}\right)$.
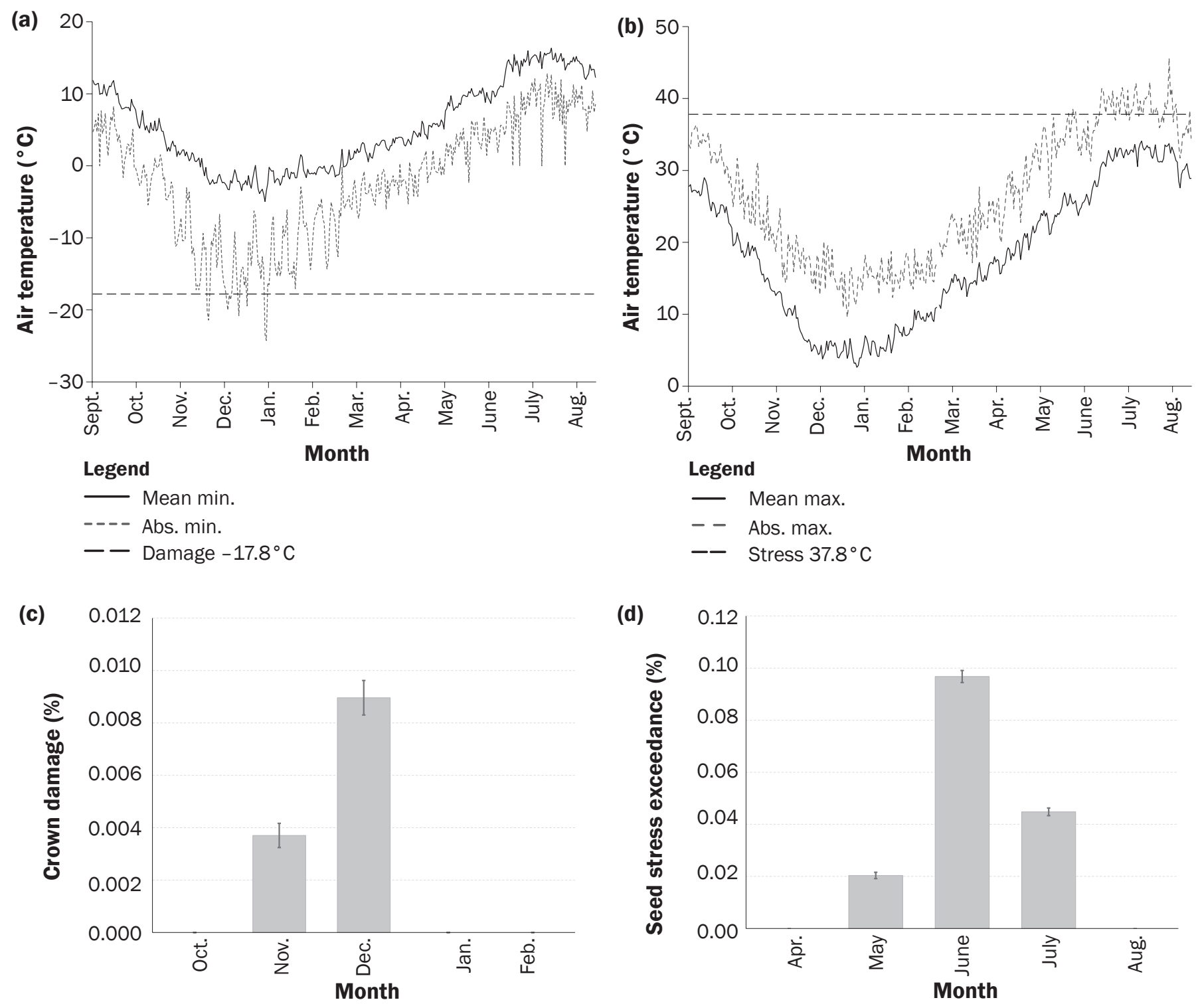

and $\left.\left.112.65 \mathrm{lb} \mathrm{ft}^{-2}\right]\right)$ corresponding approximately to $5,9,10,15$, and $40 \mathrm{~cm}(2,3.5,4,6$, and 16 in) depths below the soil surface. Soil water at individual depths and accumulated in the profile were tested for differences between treatments. Soil temperature profiles in fallow plots were measured at the soil surface, below the soil surface at $1 \mathrm{~cm}$ (0.4 in) increments up to $25 \mathrm{~cm}$ (10 in), and at depths of 30, 35, 40 , and $45 \mathrm{~cm}(12,14,16$, and $18 \mathrm{in})$ (Wuest 2010) at one-hour time steps from June 6, 2003, through September 25, 2013, and June 5, 2004, through October 16, 2014. Singlering ponded infiltrometer measurements were conducted in the final year of fallowed plots during the spring of 2018. These measurements were made by driving $30 \mathrm{~cm}(12$ in) diameter sharpened metal cylinders $20 \mathrm{~cm}$ (8 in) deep into the soil, always including one crop row inside the sample area. The inside circumference was tamped to seal any gaps between the cylinder and the soil. Water was maintained at a constant depth of 2 to $3 \mathrm{~cm}$ (0.8 to 1.2 in) with float valves for 2 hours. Readings from calibrated reservoirs provided periodic measurements of the water infiltration rate. Two hours is sufficient to achieve near steady-state infiltration in this environment (Wuest 2005; Wuest et al. 2006). Crops were harvested with a $2 \mathrm{~m}(6.6 \mathrm{ft})$ header on a plot combine with a straw chopper and spreader. Grain from each plot was weighed in a weigh wagon with $\pm 4.5 \mathrm{~kg}( \pm 9.92 \mathrm{lb})$ resolution. Representative samples were collected from each plot for protein analysis.

Data were examined to determine if transformation was needed (Gbur et al. 2012). Data were analyzed to evaluate the effect of tillage on grain yield, precipitation use efficiency, infiltration, soil water storage, and soil profile temperature. Data were analyzed using a generalized linear mixed model (GLIMMIX) in SAS 9.4 (Littell et al. 2006; SAS 2012). Soil temperature data, collected on a one-hour time step, were analyzed using 


\section{Table 1}

Winter wheat varieties and rates of seeding and fertilizer applications for crop years 2007 to 2017 in crop systems research in the 200 to $300 \mathrm{~mm}$ dryland cropping region of northeastern Oregon.

\begin{tabular}{|c|c|c|c|c|c|c|c|c|c|}
\hline $\begin{array}{l}\text { Crop } \\
\text { year }\end{array}$ & Treatment* & $\begin{array}{l}\text { Wheat } \\
\text { variety }\end{array}$ & $\begin{array}{l}\text { Sweep } \\
\text { date }\end{array}$ & $\begin{array}{l}\text { Rod- } \\
\text { weed } \\
\text { date }\end{array}$ & $\begin{array}{l}\text { Seeding } \\
\text { date }\end{array}$ & $\begin{array}{l}\text { Seeding } \\
\text { rate } \\
\left(\mathrm{kg} \mathrm{ha}^{-1}\right)\end{array}$ & $\begin{array}{l}\text { 46-0-0 } \\
\text { Drill } \\
\text { applied } \\
\left(\mathrm{kg} \mathrm{ha}^{-1}\right)\end{array}$ & $\begin{array}{l}\text { 16-20 Drill } \\
\text { applied } \\
\text { fertilizer } \\
\left(\mathrm{kg} \mathrm{ha}^{-1}\right)\end{array}$ & $\begin{array}{l}32-0-0 \\
\text { Sweep } \\
\text { applied } \\
\left(\mathrm{kg} \mathrm{N} \mathrm{ha}^{-1}\right)\end{array}$ \\
\hline 2008 & ST & Stephens & Mar. 6, 2007 & Aug. 6, 2007 & Sept. 6, 2007 & 76 & - & - & 0 \\
\hline 2009 & ST & $\begin{array}{l}\text { Tubbs06: } \\
\text { Stephens† }\end{array}$ & May 1, 2008 & - & Aug. 29, 2008 & 76 & - & - & 29 \\
\hline 2011 & ST & CF102 & June 16, 2010 & - & Sept. 21, 2010 & 56 & - & - & 0 \\
\hline 2012 & ST & CF102 & June 20, 2011 & - & Sept. 29, 2011 & 56 & - & - & 85 \\
\hline 2013 & ST & CF102 & May 30, 2012 & - & Oct. 25, 2012 & 114 & - & - & 123 \\
\hline 2014 & ST & CF102 & June 7, 2013 & - & Oct. 24, 2013 & 136 & - & - & 132 \\
\hline 2015 & ST & Bobtail & May 28, 2014 & - & Sept. 24, 2014 & 101 & - & - & 18 \\
\hline 2007 & NT & Stephens & - & - & Sept. 6, 2006 & 67 & 56 & 81 & - \\
\hline 2008 & NT & Stephens & - & - & Oct. 15, 2007 & 99 & 0 & 100 & - \\
\hline 2009 & NT & Tubbs06 & - & - & Oct 2, 2008 & 118 & 0 & 100 & - \\
\hline 2010 & NT & CF102 & - & - & Oct. 15, 2009 & 115 & 16 & 107 & - \\
\hline 2011 & NT & CF102 & - & - & Nov. 3, 2010 & 120 & 52 & 100 & - \\
\hline 2012 & NT & CF102 & - & - & Oct. 14, 2011 & 120 & 18 & 104 & - \\
\hline 2013 & NT & CF102 & - & - & Oct. 25,2012 & 114 & 23 & 102 & - \\
\hline 2014 & NT & CF102 & - & - & Oct. 24,2013 & 136 & 16 & 103 & - \\
\hline 2015 & NT & Bobtail & - & - & Oct. 17, 2014 & 114 & 16 & 0 & - \\
\hline 2016 & NT & Ovation & - & - & Oct. 16, 2015 & 130 & 0 & 103 & - \\
\hline 2017 & NT & Bobtail & - & - & Oct. 11, 2016 & 118 & 0 & 100 & - \\
\hline
\end{tabular}

*Sweep-tillage (ST) row space $36 \mathrm{~cm}$ (14 in), no-tillage (NT) row space $30 \mathrm{~cm}$ (12 in).

†Mix ratio 50:50.

this same generalized linear mixed model comparing individual means of selected, relatively consistent time periods. Satterthwaite approximation was used to estimate standard error. All data were analyzed using spatial replication as the random effect.

\section{Results and Discussion}

The NT treatment produced significantly more winter wheat $(\mathrm{NT} 3.38 \pm 0.33$, ST $2.96 \pm 0.27 \mathrm{Mg} \mathrm{ha}^{-1}$ [NT $50 \pm 5$, ST $40 \pm 4$ $\left.\mathrm{bu} \mathrm{ac}^{-1}\right]$ ) (figure $2 \mathrm{a}$ ) and had higher precipitation use efficiencies (figure 3a) from 2007 through 2018, during which two years stood out with exceptionally high differences of $p$ $\leq 0.05$ (2015 and 2017) (figures $2 b$ and 3b). Grain protein measured only in 2012, 2015, and 2017 was significantly lower in the NT $(13.37 \% \pm 0.09 \%)$ than in the ST $(14.30 \%$ $\pm 0.29 \%)$. These are high protein levels for soft white wheat, and there was never any indication that either treatment suffered from inadequate $\mathrm{N}$ supply. Volumetric soil water was not significantly different between the treatments at any depth after 14 months of fallow and immediately before seeding (figure 4). Ponded water infiltration rates measured following 12 years of treatment were significantly faster in the NT than the ST treatment $(p \leq 0.05)$ (figure 5).

Soil temperatures during summer fallow throughout the measured soil profile and all times of the day pooled from mid-June through mid-October averaged $0.16^{\circ} \mathrm{C} \pm$ $0.01^{\circ} \mathrm{C}\left(0.29^{\circ} \mathrm{F} \pm 0.02^{\circ} \mathrm{F}\right)$ cooler in the NT than in the ST $(p \leq 0.05)$. This relationship was not constant throughout this time frame, changing monthly and exhibiting a diurnal pattern of heat distribution and differences vertically in the soil profile. These findings will be discussed further in the following section. The most dynamic treatment dif- ferences occurred in the top 6 to $10 \mathrm{~cm}$ of the soil profile, where the NT was significantly cooler in the late afternoon during June, August, September, and October (June, August, and October are depicted in figure 6). Deeper in the soil profile and below this cooler zone, the soil temperature was significantly warmer during the summer in the NT than the ST $(p \leq 0.05)$.

Our expectations were for the ST to produce higher yields than the NT given the conventional wisdom that earlier seeding improves yield potential. Instead the NT outyielded the ST in all but 1 year (2012) and performed significantly better in 2015 and 2017 and for the average of 12 years (figures 2a and 2b). Precipitation in 2011 (the fallow year of the $2012 \mathrm{crop}, 325.7 \mathrm{~mm}$ [12.82 in]) and 2017 (327.2 $\mathrm{mm}$ [12.88 in]) were unusually high, outside the $95 \%$ upper 


\section{Figure 2}

(a) Twelve-year mean and (b) annual winter wheat yield produced from 2007 through 2008 with no-tillage (NT) and sweep-tillage (ST) in the low precipitation zone of the Inland Pacific Northwest. Columns with different letters are significantly different $(p \leq 0.05)$.
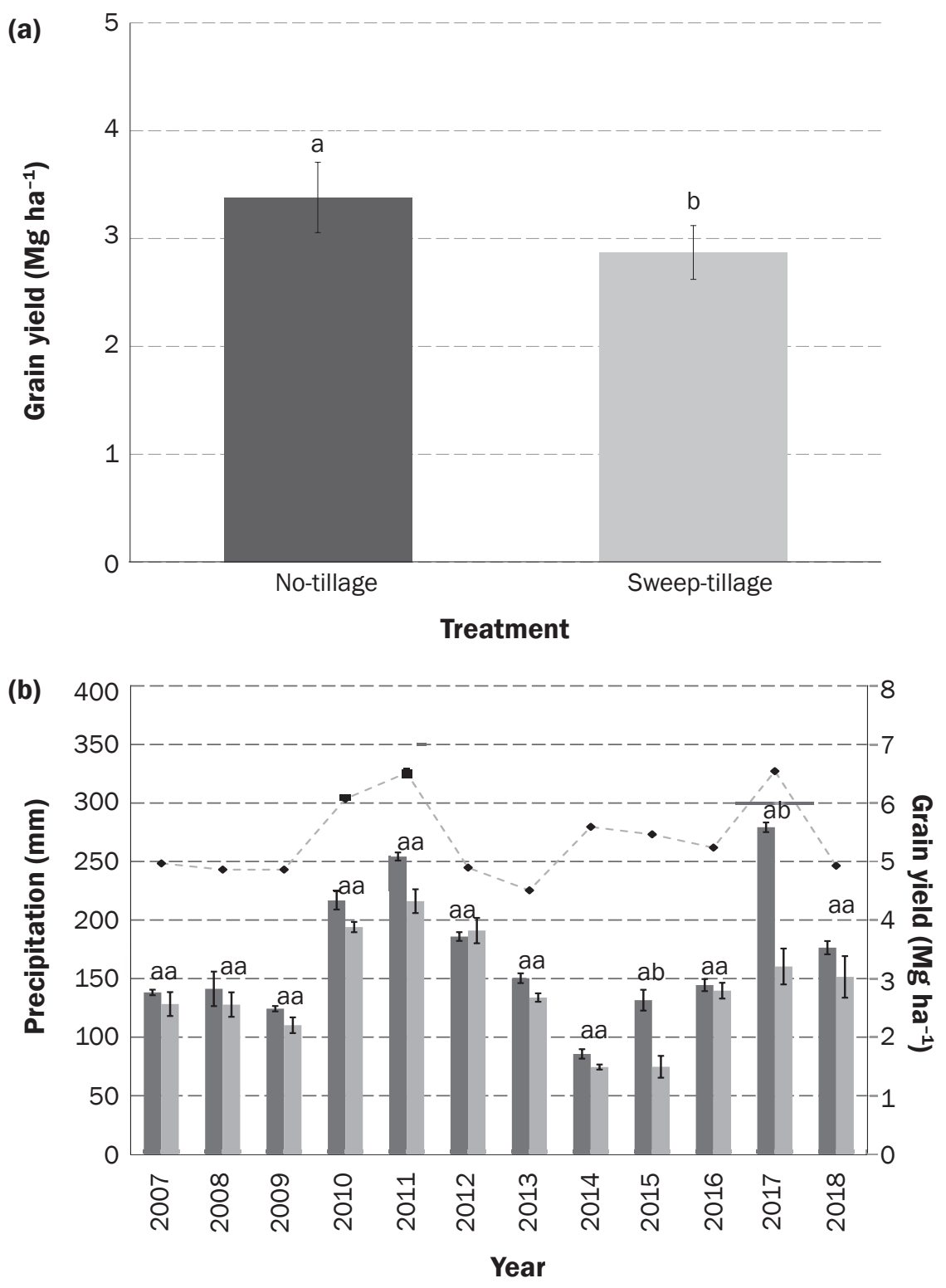

Legend

No-tillage $\quad-\bullet-$ Precipitation
Sweep-tillage

confidence level of $292.3 \mathrm{~mm}$ (11.51 in) (figure 7).

The annual precipitation for crop year 2015 was within $3 \mathrm{~mm}$ (0.12 in) of the mean value recorded since 2001 and within the range of precipitation where treatment yields were not significantly or substantially different. The ST crop was seeded a full month before the NT (September 24 versus October 24). Precipitation was below normal until December of that year, but the NT was seeded immediately after the first precipitation of the crop year at or above normal growing degree days (heat units).
Unfortunately, soil water measurements were not taken from within the plots in the autumn of 2014. Analysis of soil water measurements in an adjacent reduced tillage research project that year did not show significant differences in soil water taken at $30 \mathrm{~cm}$ (12 in), $60 \mathrm{~cm}$ (24 in), $120 \mathrm{~cm}$ (48 in), or throughout the entire profile in the autumn of 2014 compared to 2015, 2016, or 2017. Those results suggest that the soil water was not exceptionally low, and lack of it should not have been responsible for later germination or poor stand establishment. Although precipitation in 2015 was below or at a normal level until May (figure 7), significantly more precipitation fell than normal in May and June. The additional rain possibly infiltrated more readily into the NT and contributed to a greater yield than in the ST.

Dryland crop research in the low and intermediate precipitation zones of the Inland Pacific Northwest has largely focused on precipitation captured during the fallow year and the subsequent soil water storage through the hot and dry months of June, July, and August (Al-Mulla et al. 2009; Schillinger 2001; Schillinger and Bolton 1993; Williams et al. 2014; Wuest 2010). Soil water dynamics are controlled by soil texture, soil structure, differential vapor pressure, temperature, and interactive water and heat transport processes (Al-Mulla et al. 2009). In soil where tillage destroyed structure, precipitation can be trapped at or near the surface and evaporate. Once precipitation has infiltrated into the soil profile, it can biologically transpire, percolate deeper, or evaporate. Typically, most precipitation that falls in this region after March through mid-June will not runoff due the small drop size and low intensity (Williams 2008; Williams et al. 1998). This will contribute to increased yields during crop years (Machado et al. 2015; Schillinger et al.2008) and stored water in fallow years if it does not evaporate before percolating into the root zone. Recent research (Williams et al. 2018) shows more intensive tillage/disturbance of these soils can lead to an increase in the small and subaggregate size classes that contribute to surface sealing, reduced infiltration rates, and increased precipitation retention at the soil surface where it will more likely evaporate.

Seed-zone moisture in autumn following a dry summer is largely dependent on the capillary rise of soil water (see Castillo et al. [2015] for application in distributed hydro- 


\section{Figure 3}

(a) Twelve-year mean precipitation use efficiency (PUE) and (b) annual mean precipitation use efficiency values under no-tillage (NT) and sweep-tillage (ST) winter wheat production in the low precipitation zone of the Inland Pacific Northwest. Columns or annual values with different letters or asterisks are significantly different $(p \leq 0.05)$.
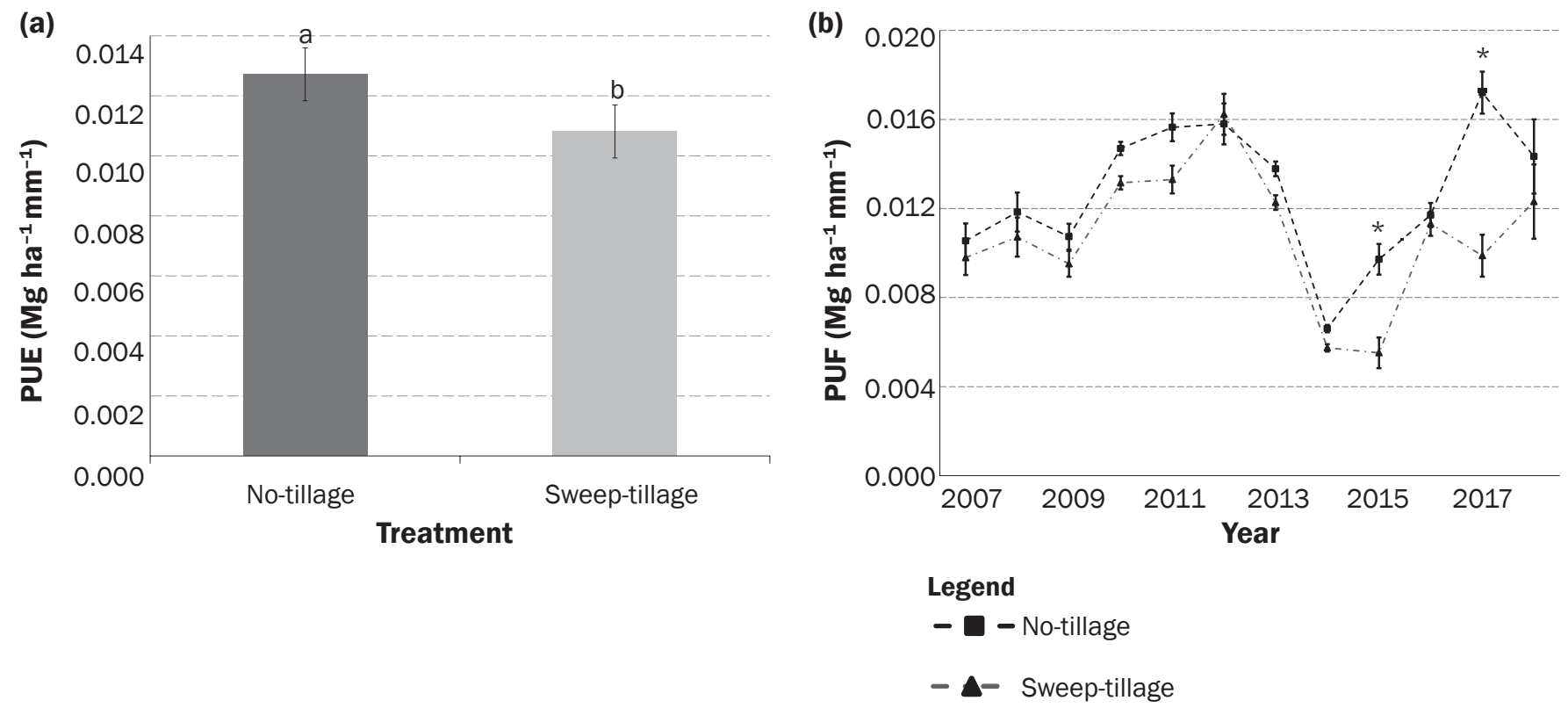

\section{Figure 4}

Soil water in no-tillage (NT) and sweep-tillage (ST) winter wheat production in the low precipitation zone of the Inland Pacific Northwest after 14 months of fallow and before seeding. Depths were compared at soil accumulated equivalent mass depths: 50, 100, 125, 225, and $550 \mathrm{~kg} \mathrm{~m}^{-2}$ are approximately equal to $5,9,10,15$, and $40 \mathrm{~cm}$ below the soil surface.

\section{Soil Water $\theta\left(\mathrm{cm}^{3} \mathrm{~cm}^{-3}\right)$}

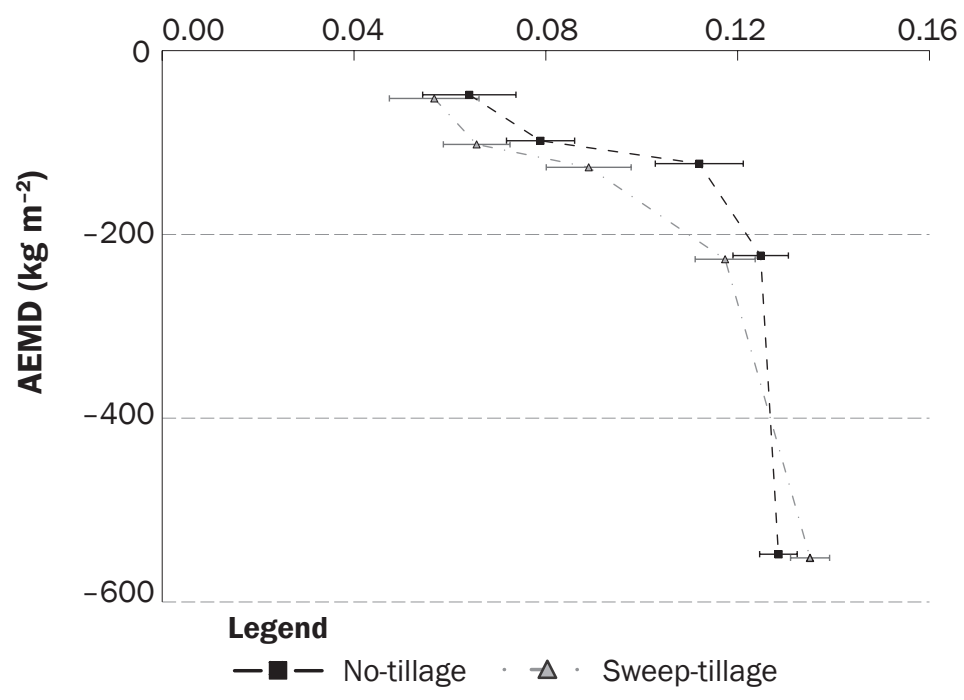

logic models). Although our soil water data at planting were not statistically significantly different between the NT and ST treatments, greater yield would indicate greater water availability in the NT system. Examination of total soil water deeper than $10 \mathrm{~cm}$ (4 in) in the soil profile reveals marginally more (but not statistically significant) soil water in the
ST profile following fallow and immediately before seeding (figure 8). These data indicate chemically fallowed soil water conductivity is continuous with no interruption to the soil surface, creating a gradient in soil water content without a substantial difference in the total evaporation found in ST. These results also suggest that the ST treatment should have produced as much or more grain based on the relationship of water stored after summer fallow: $0.008 \mathrm{Mg} \mathrm{ha}^{-1} \mathrm{~mm}^{-1}$ (7.3 $\mathrm{bu} \mathrm{ac}^{-1}$ $\mathrm{in}^{-1}$ ) (Schillinger et al. 2008). With a $2.46 \mathrm{~mm}$ (0.10 in) greater mean water storage (not statistically significant), the ST should have outproduced the NT by $0.003 \mathrm{Mg} \mathrm{ha}^{-1}(0.73$ bu $\mathrm{ac}^{-1}$ ), but instead the NT had significantly higher production (figures $2 \mathrm{a}$ and $2 \mathrm{~b}$ ).

There has been limited research published in the Pacific Northwest concerning soil temperatures. Al-Mulla et al. (2009) reported higher soil temperatures in NT fallow than in reduced tillage fallow at Lind, Washington, from May through March. Recorded at 2.5 $\mathrm{cm}$ (1 in), $12.5 \mathrm{~cm}$ (5 in), and $17.5 \mathrm{~cm} \mathrm{(7}$ in), NT was $1.3^{\circ} \mathrm{C}\left(2.34^{\circ} \mathrm{F}\right), 1.1^{\circ} \mathrm{C}\left(1.98^{\circ} \mathrm{F}\right)$, and $1.0^{\circ} \mathrm{C}\left(1.80^{\circ} \mathrm{F}\right)$ warmer at their site, whereas NT at our site was cooler in the shallower depth during daylight hours into the evening except during July's peak air and soil temperatures (figure 6): June $\left(0.08^{\circ} \mathrm{C} \pm\right.$ $\left.0.02^{\circ} \mathrm{C}\left[0.14^{\circ} \mathrm{F} \pm 0.04^{\circ} \mathrm{F}\right]\right)$, August $\left(0.76^{\circ} \mathrm{C}\right.$ $\left.\pm 0.08^{\circ} \mathrm{C}\left[1.37^{\circ} \mathrm{F} \pm 0.14^{\circ} \mathrm{F}\right]\right)$, September 


\section{Figure 5}

Ponded water infiltration rates in no-tillage (NT) and sweep-tillage (ST) winter wheat crops produced in the low precipitation zone of the Inland Pacific Northwest. Columns with different letters are significantly different $(p \leq 0.05)$.

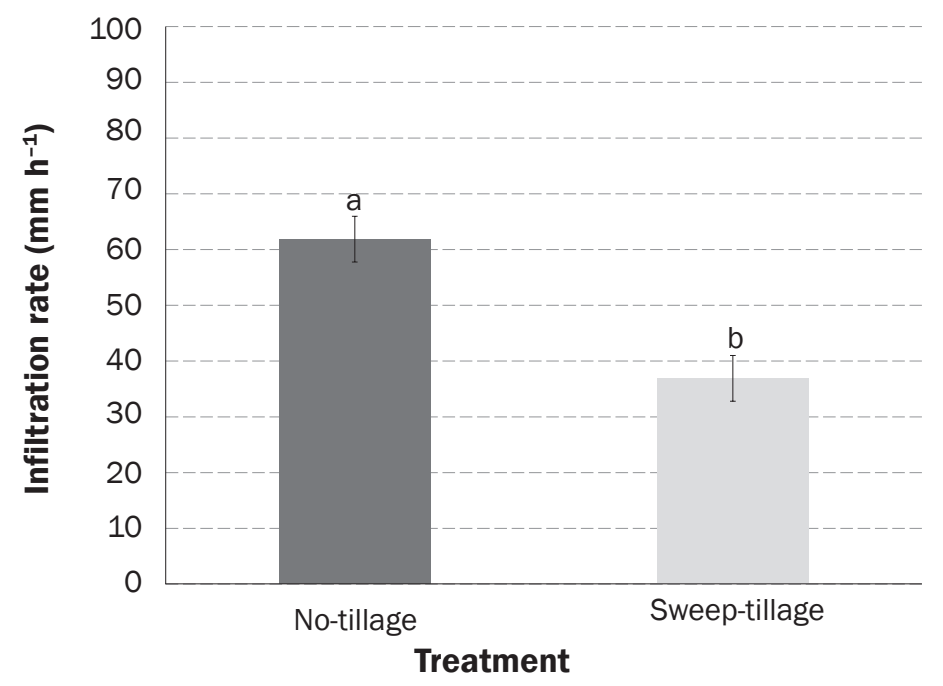

$\left(0.25^{\circ} \mathrm{C} \pm 0.02^{\circ} \mathrm{C}\left[0.45^{\circ} \mathrm{F} \pm 0.04^{\circ} \mathrm{F}\right]\right)$, and October $\left(0.59^{\circ} \mathrm{C} \pm 0.05^{\circ} \mathrm{C}\left[1.06^{\circ} \mathrm{F} \pm\right.\right.$ $\left.\left.0.09^{\circ} \mathrm{F}\right]\right)$. At the $20 \mathrm{~cm}(8 \mathrm{in})$ and $45 \mathrm{~cm}(18$ in) depths, mean temperatures were statistically higher in the NT through much of the day during August but not October. Temperatures in both treatments at $45 \mathrm{~cm}$ (18 in) fully merged in October.

The difference between our findings and those of Al-Mulla et al. (2009) might well be the difference between our data collected over the course of two summers and their data collected for one spring, summer, autumn, winter, and early spring cycle. However, our results differed in other substantial points. Al-Mulla et al. (2009) propose that two conditions could have led to higher temperatures in NT: soil bulk density and soil surface albedo. Lower bulk density could increase heat loading, resulting from lower thermal diffusivity in the conventional fallow (Al-Mulla et al. 2009). We found no differences in soil bulk density down to a depth of $40 \mathrm{~cm}$ (16 in) for NT (1.37 \pm $\left.0.01 \mathrm{~g} \mathrm{~cm}^{-3}\left[0.05 \pm 0.00 \mathrm{lb} \mathrm{in}^{-3}\right]\right)$ and ST $\left(1.30 \pm 0.01 \mathrm{~g} \mathrm{~cm}^{-3}\left[0.05 \pm 0.00 \mathrm{lb} \mathrm{in}^{-3}\right]\right)$. The lower bulk density in the reduced tillage recorded by Al-Mulla et al. (2009) was likely the result of the June or July pass by a rod weeder they performed that we did not. This additional tillage is one possible explanation for lower temperatures in their reduced tillage treatment than was found in ours. We did not measure albedo or ground covered by crop residue; visually nearly $100 \%$ cover was attained in both treatments by straw from the previous crop and fallow cycle. Therefore, both treatments were equally capable of insulating the soil surface and reflecting much of the solar energy. Finally, data collected by Al-Mulla et al. (2009) were collected and analyzed on a daily time step and thus not able to capture the diurnal nuance. Our results are more similar to those found by Shen et al. (2018) who took measurements at a $10 \mathrm{~cm}$ (4 in) depth in maize (Zea mays L.) and soybeans (Glycine max L.) in northeast China with annual temperatures of $4.4^{\circ} \mathrm{C}\left(7.92^{\circ} \mathrm{F}\right)$ and found temperatures were $0^{\circ} \mathrm{C}$ to $1.5^{\circ} \mathrm{C}\left(0^{\circ} \mathrm{C}\right.$ to $\left.2.70^{\circ} \mathrm{F}\right)$ cooler following seeding in NT compared to moldboard plow tillage. These measurements were also analyzed on a daily time step, but they found different results from year to year and biweekly time periods within years when the tillage treatment temperatures relative to each other switched.

We do not believe that soil temperature alone can explain the differences in the crop production of these two systems. The soil profile temperature difference from June through October of $-0.07^{\circ} \mathrm{C}\left(-0.13^{\circ} \mathrm{F}\right)$ in the NT probably makes only a small physiological difference to the production of wheat. Although the soil profile was cooler in the NT treatment, that difference was concentrated in the soil surface and during the sunlit hours of the day; otherwise, there was no difference in soil temperature at or near the surface, and the temperatures deeper in the soil profile were significantly warmer in the NT than in the ST. More than two years of data collected throughout the entire twoyear crop-fallow cycle would have provided a more revealing view of the role of soil temperature in this system. We also note that the temperature data were not collected during the years in this study when NT significantly outproduced ST.

Early seeding in low rainfall zones is subject to several hazards, including excessive water use, soil crusting before emergence, and insufficient seed-zone water for uniform emergence. At our site, the early seeded ST treatment attracted noticeably more rodent activity, which likely contributed to lower yields. Even well-established best management practices will not perform as reliably on the margins of the climate zone where they have proven adequate. In contrast, at this site the NT seeding was consistently uniform in emergence and development.

Research from similar climates and cropping systems produced comparable results, including areas surrounding the Mediterranean (Amato et al. 2013; Bassu et al. 2009; Moret et al. 2007; Sommer et al. 2012) and in Australia (Hunt et al. 2013; Ward et al. 2012). In general, these research projects demonstrated that tillage or NT were not the primary factor in crop yield and that, specifically, crop residue on the soil surface has a relatively minor effect on yield (Hunt et al. 2013; Sommer et al. 2012). It does appear that NT can outyield tilled systems under high water stress (Amato et al. 2013) but only with adequate weed control during fallow to conserve stored water (Bassu et al. 2009; Hunt et al. 2013). Worldwide NT could prove to be the most resource efficient and economic system in the driest winter wheat growing regions.

\section{Summary and Conclusions}

The purpose of this research was to evaluate the productivity of NT and minimum tillage winter wheat-fallow systems. Each system was applied with standard practices used by producers in the low precipitation zone of the US Pacific Northwest. The NT system produced significantly higher crop yields and higher precipitation use efficiencies than the ST system. The later NT seeding dates did not adversely affect grain yields relative to the ST grain yields. There were significant differences between the tillage systems' physical characteristics: infiltration rates were higher and soil temperatures were lower in the NT system. The higher yields and lower soil tem- 


\section{Figure 6}

Soil temperatures late in (a) June, (b) July, and (c) August before seeding and in (d) October shortly before or after seeding crops in no-tillage (NT) and sweep-tillage (ST) winter wheat production located in the low precipitation zone of the Inland Pacific Northwest. Treatment difference is significant where * occurs above standard error bars $(p \leq 0.05)$.
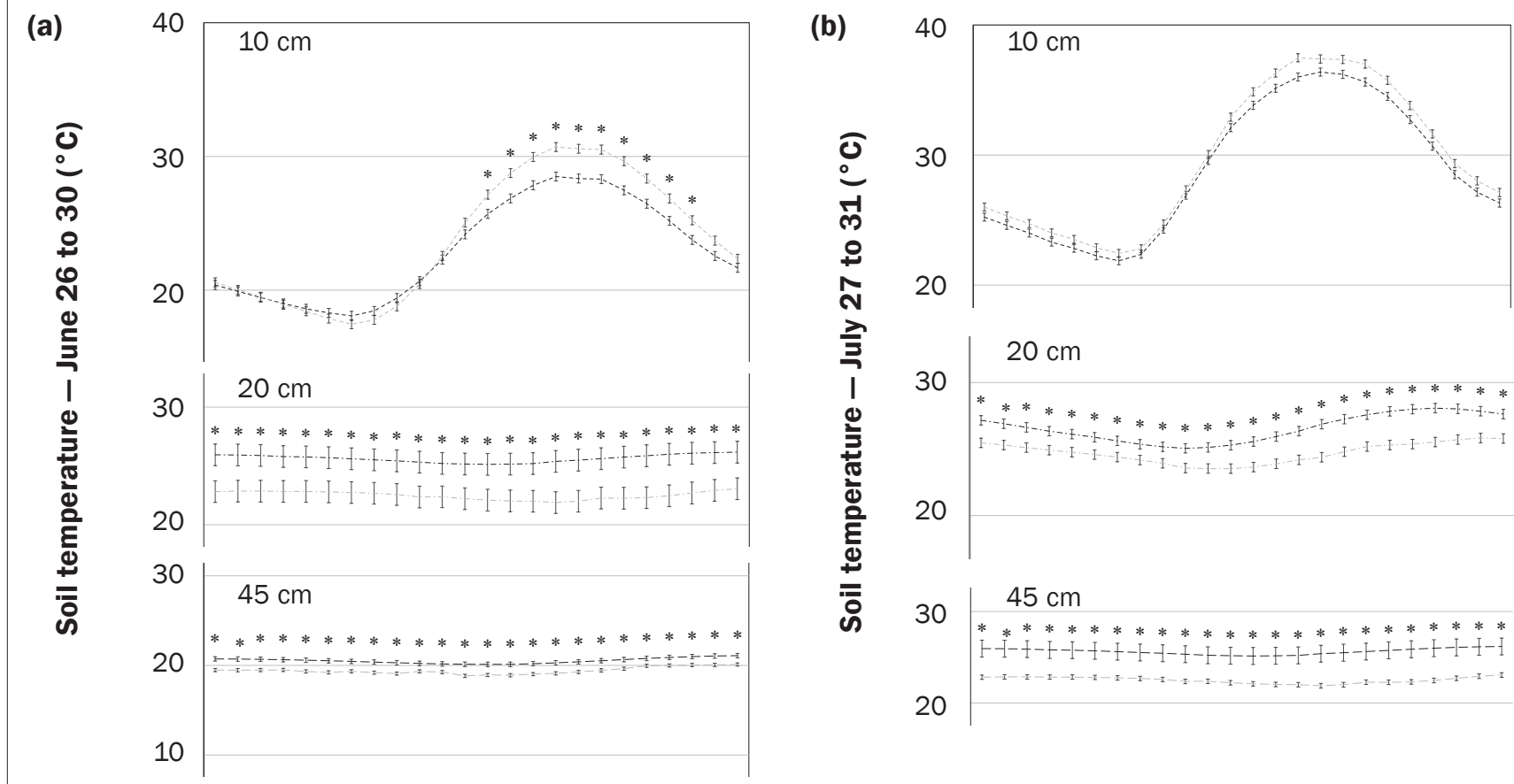

(c)

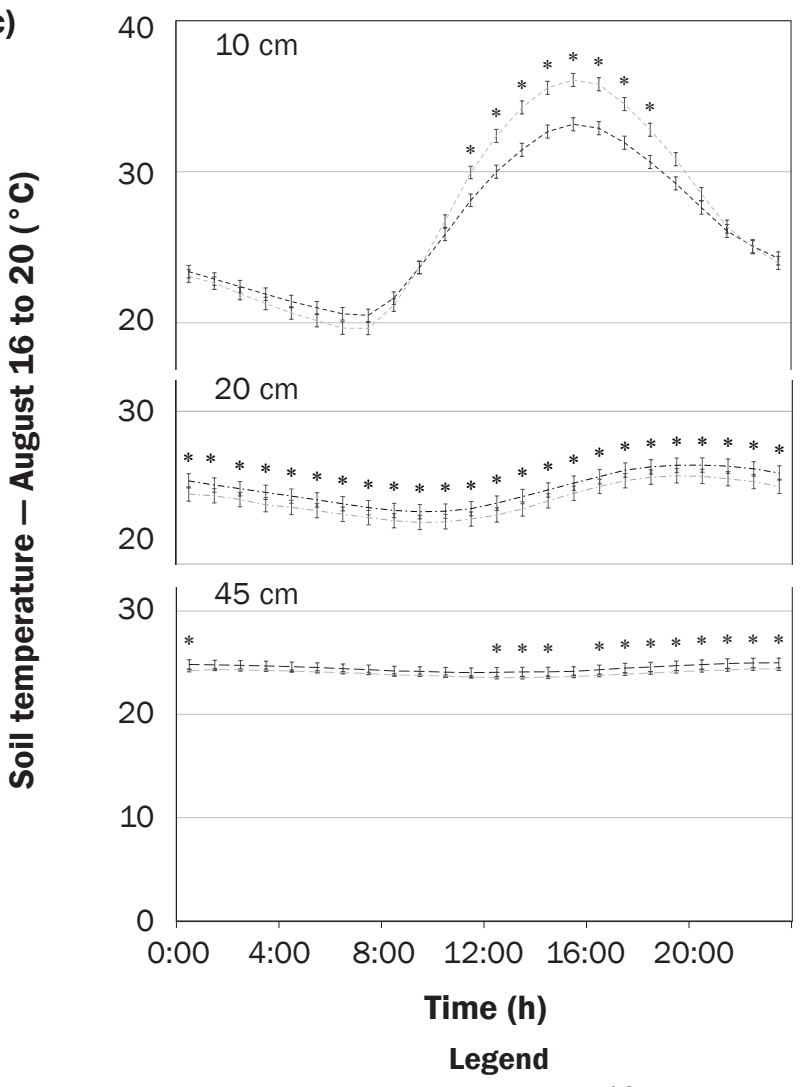

(d)

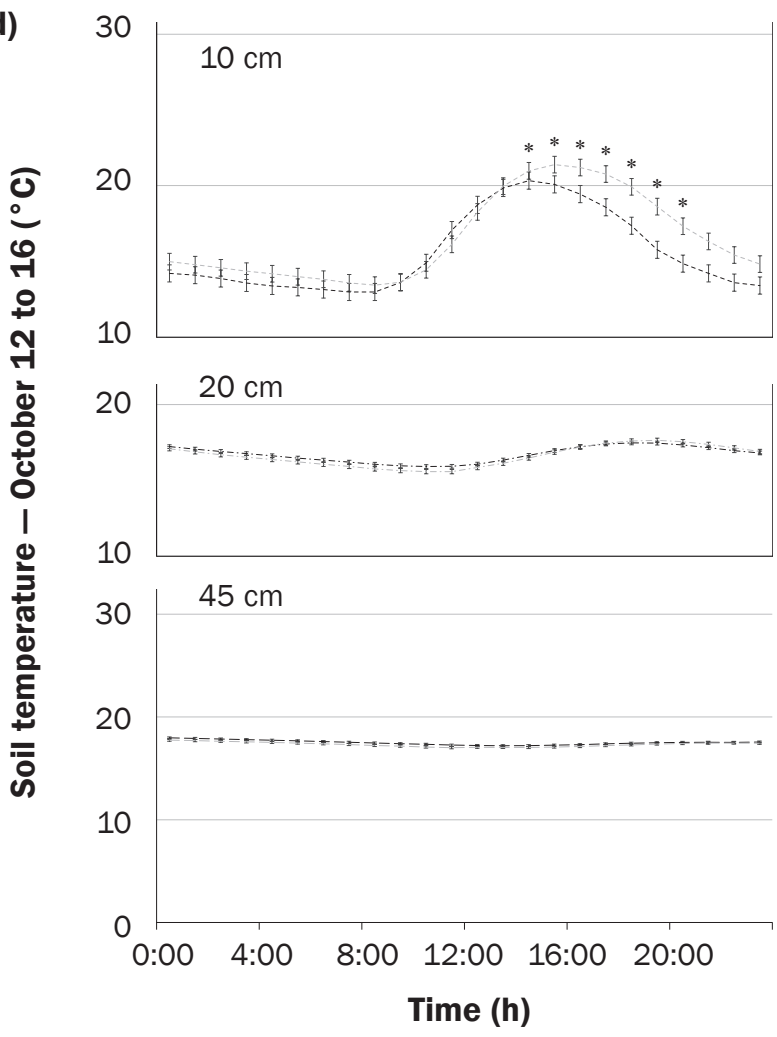
- - - NT $10 \mathrm{~cm}$
NT $20 \mathrm{~cm}$
- NT $45 \mathrm{~cm}$
ST $10 \mathrm{~cm}$
ST $20 \mathrm{~cm}$
ST $45 \mathrm{~cm}$ 


\section{Figure 7}

Mean and standard deviation monthly precipitation (2001 to 2018) in relation to high productivity years in the no-tillage (NT) treatment $(2011,2015$, and 2017) from data collected at the research site in the low precipitation zone of the Inland Pacific Northwest.

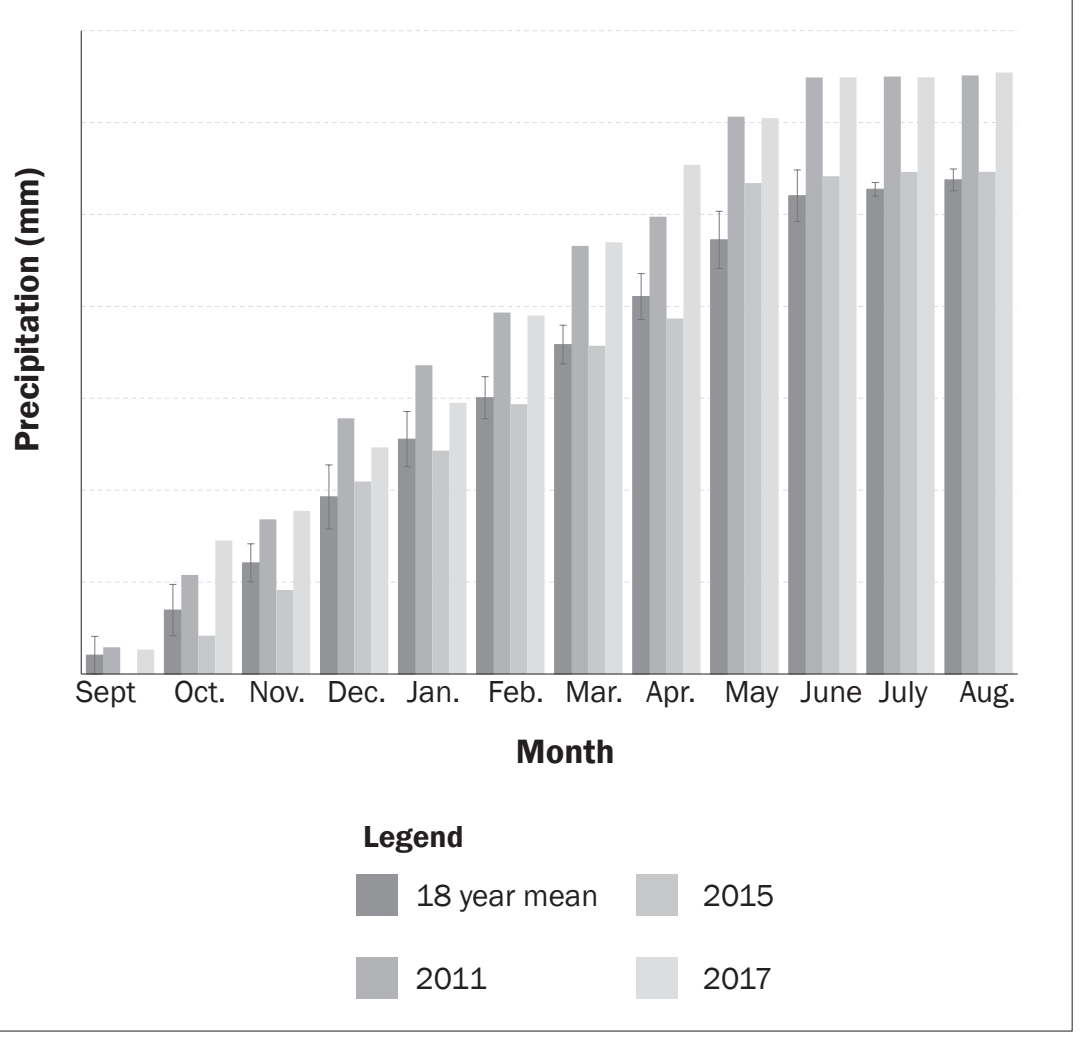

Figure 8

Soil water in the 10 to $100 \mathrm{~cm}$ depth at seeding in no-tillage (NT) and sweep-tillage (ST) winter wheat production located in the low precipitation zone of the Inland Pacific Northwest.

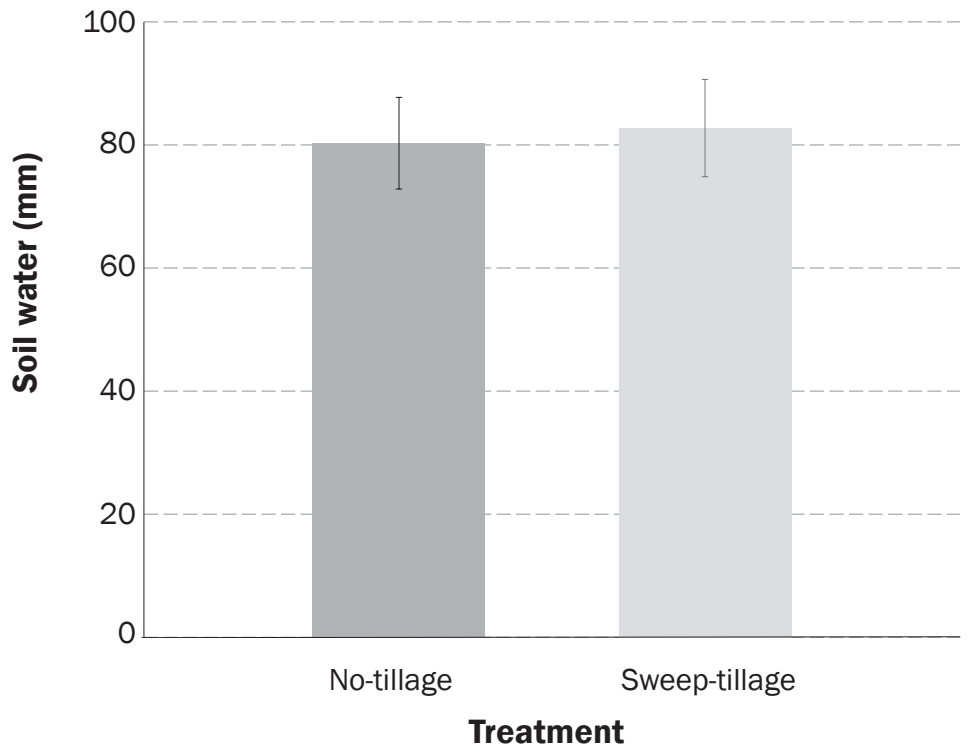

peratures in the NT system were unexpected and contrary to previous research conducted in this region. Understanding what factors caused the differences in yield would aid in developing improvements for both tilled and NT systems.

\section{Supplemental Material}

The supplementary material for this article is available in the online journal at https://doi.org/10.2489/jswc.2021.00062.

\section{References}

Al-Mulla, Y.A., J.Q. Wu, P. Singh, M. Flury, W.F. Schillinger, D.R. Huggins, and C.O. Stöckle. 2009. Soil water and temperature in chemical versus reduced-tillage fallow in a Mediterranean Climate. Applied Engineering in Agriculture 25(1):45-54.

Amato, G., P. Ruisi, A.S. Frenda, G. Di Miceli, S. Saia, A. Plaia, and D. Giambalvo. 2013. Long-term tillage and crop sequence effects on wheat grain yield and quality. Agronomy Journal 105(5):1317-1327.

Bassu, S., S. Asseng, R. Motzo, and F. Giunta. 2009. Optimising sowing date of durum wheat in a variable Mediterranean environment. Field Crops Research 111(1):109-118.

Bista, P., S. Machado, R. Ghimire, G.Yorgey, and D.J.Wysocki. 2017. Conservation tillage systems. In Advances in Dryland Farming in the Inland Pacific Northwest, eds. G. Yorgey and C.E. Kruger, 99-124. Pullman, Washington: College of Agricultural, Human, and Natural Resource Sciences, Washington State University.

Castillo, A., F. Castelli, and D. Entekhabi. 2015. Gravitational and capillary soil moisture dynamics for distributed hydrologic models. Hydrology and Earth System Sciences 19(4):1857-1869.

Donaldson, E., W.F. Schillinger, and S.M. Dofing. 2001. Straw production and grain yield relationships in winter wheat. Crop Science 41(1):100-106.

FAO (Food and Agricultural Organization). 1997. FAO/ Unesco Soil Map of the World, Revised Legend, with Corrections and Updates. International Soil Reference and Information Centre:Wageningen, Netherlands: FAO.

Gbur, E.E., K.S. McCarter, S. Durham, L.J. Young, M. Christman, M. West, and M. Kramer. 2012. Repeated measures in time and space. In Analysis of Generalized Linear Mixed Models in the Agricultural and Natural Resources Sciences, 199-210. Madison, Wisconsin: American Society of Agronomy, Soil Science Society of American, and Crop Science Society of America.

Gollany, H.T., R.W. Rickman, Y. Liang, S.L. Albrecht, S. Machado, and S. Kang. 2011. Predicting agricultural management influence on long-term soil organic carbon dynamics: Implications for biofuel production. Agronomy Journal 103(1):234-246.

Hunt, J.R., C. Browne, T.M. McBeath, K. Verburg, S. Craig, and A.M.Whitbread. 2013. Summer fallow weed control and residue management impacts on winter crop yield 
through soil water and $\mathrm{N}$ accumulation in a winterdominant, low rainfall region of southern Australia. Crop and Pasture Science 64(9):922-934.

Johnson, D.R., and A.J. Makinson. 1988. Soil Survey of Umatilla County Area, Oregon. Washington, DC: USDA Soil Conservation Service, US Government Printing Office.

Littell, R.C., G.A. Milliken, W.W. Stroup, R.D.Wolfinger, and O. Schabenberger. 2006. SAS for Mixed Models, Second Edition. Cary, NC: SAS Publishing.

Lutcher, L.K., W.F. Schillinger, S.B. Wuest, N.W. Christensen, and D.J. Wysocki. 2010. Phosphorus fertilization of lateplanted winter wheat into no-till fallow. Agronomy Journal 102(2):868-874.

Machado, S., L. Pritchett, and S. Petrie. 2015. No-tillage cropping systems can replace traditional summer fallow in north-central Oregon. Agronomy Journal 107(5):1863-1877.

Moret, D., I. Braud, and J.L. Arrúe. 2007. Water balance simulation of a dryland soil during fallow under conventional and conservation tillage in semiarid Aragon, Northeast Spain. Soil and Tillage Research 92(1):251-263.

SAS. 2012. SAS/STAT 9.4 User's Guide. Cary, NC: SAS Institute Inc.

Schillinger, W.F. 2001. Minimum and delayed conservation tillage for wheat-fallow farming. Soil Science Society of America Journal 65(4):1203-1209.

Schillinger,W.F. 2007. Ecology and control of Russian thistle (Salsola iberica) after spring wheat harvest. Weed Science 55(4):381-385.

Schillinger, W.F., and F.E. Bolton. 1993. Fallow water storage in tilled vs. untilled soils in the Pacific Northwest. Journal of Production Agriculture 6(2):267-269.

Schillinger, W.F., and R.I. Papendick. 2008. Then and now: 125 years of dryland wheat farming in the Inland Pacific Northwest. Agronomy Journal 100(Supplement_3):S-166-S-182.

Schillinger, W.F., S.E. Schofstoll, and J.R. Alldredge. 2008. Available water and wheat grain yield relations in a Mediterranean climate. Field Crops Research 109(1-3):45-49.

Sharratt, B., F. Young, and G. Feng. 2017. Wind erosion and pm10 emissions from no-tillage cropping systems in the Pacific Northwest. Agronomy Journal 109(4):1303-1311.

Sharratt, B.S., and G. Feng. 2009. Windblown dust influenced by conventional and undercutter tillage within the Columbia Plateau, USA. Earth Surface Processes and Landforms 34(10):1323-1332.

Shen,Y., N. McLaughlin, X. Zhang, M. Xu, and A. Liang. 2018. Effect of tillage and crop residue on soil temperature following planting for a Black soil in Northeast China. Scientific Reports 8(1):4500.

Smiley, R.W., J.M. Marshall, J.A. Gourlie, T.C. Paulitz, S.L. Kandel, M.O. Pumphrey, K. Garland-Campbell, et al. 2013. Spring wheat tolerance and resistance to
Heterodera avenae in the Pacific Northwest. Plant Disease 97(5): 590-600.

Sommer, R., C. Piggin, A. Haddad, A. Hajdibo, P. Hayek, and Y. Khalil. 2012. Simulating the effects of zero tillage and crop residue retention on water relations and yield of wheat under rainfed semiarid Mediterranean conditions. Field Crops Research 132(0):40-52.

Thorup-Kristensen, K., M. Salmerón Cortasa, and R. Loges. 2009. Winter wheat roots grow twice as deep as spring wheat roots, is this important for $\mathrm{N}$ uptake and $\mathrm{N}$ leaching losses? Plant and Soil 322(1):101-114.

Ward, P.R., K.C. Flower, N. Cordingley, C. Weeks, and S.F. Micin. 2012. Soil water balance with cover crops and conservation agriculture in a Mediterranean climate. Field Crops Research 132:33-39.

Williams, J.D. 2008. Soil erosion from dryland winter wheatfallow in a long-term residue and nutrient management experiment in north-central Oregon. Journal of Soil and Water Conservation 63(2):53-59. https://doi. org/10.2489/jswc.63.2.53.

Williams, J.D., and D.S. Long. 2011. Intensive crop rotation yield and economic performance in minimum tillage and no tillage in Northeastern Oregon. Crop Management 10(1).

Williams, J.D., C.L. Reardon, S.B. Wuest, and D.S. Long. 2018. Soil wet aggregate stability in dryland Pacific Northwest intensified crop rotations. Soil Science Society of America Journal 82(2):455.

Williams, J.D., D.E. Wilkins, D.K. McCool, L.L. Baarstad, B.K. Klepper, and R.I. Papendick. 1998. A new rainfall simulator for use in low-energy rainfall areas. Applied Engineering in Agriculture 14(3):243-247.

Williams, J.D., S.B. Wuest, and D.S. Long. 2014. Soil and water conservation in the Pacific Northwest through no-tillage and intensified crop rotations. Journal of Soil and Water Conservation 69(6):495-504. https://doi. org/10.2489/jswc.69.6.495.

Wuest, S.B. 2005. Bias in ponded infiltration estimates due to sample volume and shape.Vadose Zone Journal 4:11831190. doi:10.2136/vzj2004.0184.

Wuest, S.B. 2009. Correction of bulk density and sampling method biases using soil mass per unit area. Soil Science Society of America Journal 73(1):312-316

Wuest, S.B. 2010. Tillage depth and timing effects on soil water profiles in two semiarid soils. Soil Science Society of America Journal 74(5):1701-1711.

Wuest, S.B., J.D. Williams, and H.T. Gollany. 2006. Tillage and perennial grass effects on ponded infiltration for seven semi-arid loess soils. Journal of Soil and Water Conservation 61(4):218-223.

Zaiken, A.A., D.L. Young, and W.F. Schillinger. 2008. Economic comparison of undercutter and traditional tillage systems for winter wheat-summer fallow farming. Advancing Sustainable Agriculture in the Pacific Northwest, Conservation Tillage Systems Information Resource, Conservation Tillage Update Newsletter,
May 2008. Pullman, WA: Solutions to Environmental and Economic Problems.

Zuzel, J.F. 1994. Runoff and soil erosion phenomena in the dryland grain growing region of the Pacific Northwest, USA. Trends in Hydrology 1(1):209-216. 